\title{
Islamisation of the Muslim World
}

\section{Yasmin Rehman*}

*Correspondence: msyasmin.rehman@gmail.com

Through the erasure of cultural practices and a denial of the diversity of

Muslims and Islamic practices across the world, Islamists are reinforcing

their world view and creating a homogenous, monolithic Muslim identity, an identity in which culture and history are to be separated from Islam and Islamic practice, in which there is no space for ethnic or tribal identities, and where national, regional and local boundaries are irrelevant. This is a world in which only the boundaries of the Ummah (Muslim world) count, where there is only one law, religious law (Sharia), and in which an identity in which the separation of religion and state is heretical. The religious community is the state, the Ummah is the community, every aspect of one's life is circumscribed by religion and women, their lives and their bodies are the battleground. Anything that

(C) Copyright: The Authors. This article is issued under the terms of the Creative Commons Attribution NonCommercial Share Alike License, which permits use and redistribution of the work provided that the original author and source are credited, the work is not used for commercial purposes and that any derivative works are made available under the same license terms. does not fit with their world view is simply swept away as not Islamic.

Their message and teachings are spread through extensive use of social media, satellite broadcast channels, podcasts, conferences and events, local religious bookshops, study circles, mosques and the establishment of Islamic institutions including schools and Sharia courts. In this article I equate Islamism with Salafis', 'a term which literally means predecessors but in the Islamic context means those who follow the practices of the 
first generation of Muslims' (Bowen, 2014). Many Salafis follow the dominant ideology of Saudi Arabia also the home of Wahabbi Islam. ${ }^{i i}$

In this article I present evidence of the ways in which I believe Islamist movements are utilizing the creation of a single 'authentic' Muslim identity as part of their political cause. I draw upon my own personal experiences as a woman of Muslim heritage and draw upon original research I have undertaken which explores the impact of the imposition of an Islamist Muslim identity on women in London. The research involved in-depth interviews with 14 women aged between 19 and 75 years of age. All the participants identified as Muslims and of South Asian (Indian and Pakistani) origin and descent. Whilst the focus of this research has been on these specific communities the Islamist iconoclastic mission is not limited to South Asians or to Muslims in Britain.iii

Idols, Icons and Culture

In March 2001, the Taliban destroyed the 1,700 year old Bamiyan Buddhas in central Afghanistan. In Iraq, ISIL (Islamic State) has destroyed ancient ruins in the cities of Hatra and Nimrud, obliterated artefacts from a museum in Mosul that are even older than the Bamiyan Buddhas and destroyed the Temple of Bel in the ancient city of Palmyria in Syria. The accepted view is that ISIL, the Taliban, Al Qaeda and others are destroying ancient monuments for iconoclastic religious reasons. However, it is also an action of attacking or assertively rejecting 
cherished beliefs and institutions and/or established values and practices. Abrahamic traditions - Judaism, Christianity and Islam - have a history of iconoclastic zealotry. Islamist movements have been using this approach to impose their 'authentic Islam' upon Muslims across the world by destroying what they see as 'idols' and indeed anything which can interfere with their interpretation of Islam. Islamist movements have banned music in Afghanistan (Baily, 2001), Mali (Denselow, 2013) and Libya (Bacchi, 2015), are exerting ever increasing control of women's movement in public spaces, imposing religious dress codes and attacking and murdering anyone who dares to dissent, as can be seen from the murders of secular writers and bloggers in Bangladesh and the imprisonment of journalists in Turkey. Anand Veeraraj states:

Idolatry is anything that thwarts the worship of the Living God who brings forth new life and transformation. Idols by nature constrict the movement of the divine spirit and foil new creation from emerging. Idols are not limited to images and statues alone. At times, our ideologies, doctrines, theologies, rituals, liturgies, languages, creeds, dogmas, scriptures, sacred places, cultic personalities, denominations and institutions may turn into idols. When that happens, we should not hesitate to smash them down or discard them altogether. ${ }^{\text {iv }}$

I would argue that the Islamist project concurs with Veeraraj's description of 'idols' as can be seen from its determination to erase any practices that do not sit within its austere and puritanical interpretation of Islam by 
labelling them as 'cultural' and not Islamic. This concern with homogenising Islamic religious practices is supported by extremists and those often considered liberal and/or reformist. Tariq Ramadan (2004) seen by many as a progressive Islamic scholar, criticizes the confusion between culture and Islam. He suggests that Muslims themselves conflate the two things, especially if adherents in a country that cannot speak the language of the Qu'ranic scriptures. The vast majority of Muslims do not speak Qu'ranic Arabic, although most will learn to read the text without an understanding of the language. Ramadan argues this is made worse if, as is the case in much of the West, there are no local and authoritative Islamic institutions. Ramadan argues that Western Muslims need to learn to observe Islam without letting local cultural practices interfere. This distinction between cultural and religious practices has begun to permeate much of the discourse with liberals and progressives arguing that problematic practices such as forced marriage and honour based violence are related to culture and not religion and therefore the two should be distinguished. Ramadan's call is certainly being heeded by the Islamists as can be seen from the adoption of Salafi practices as authentic and rooted in the universe of Islam. This is in stark contrast to 'cultural' practices anything the Salafis do not agree with. But can religious practice be completely separated and divorced from cultural practice? Did Islam - a faith born in what is now Saudi Arabia - completely reject all that went before? I do not think so. The Ottoman Empire was sustained and inspired by Islam and Islamic institutions, and, in order to survive it would have 
taken on and merged with local cultures. But prior to this, early Muslims adopted and modified practices associated with the jahiliyya, for example in terms of local food laws and polygamy. ${ }^{v}$ Instead of having unlimited numbers of wives, Islam limited the number of wives a man could have to four at any one time. Some practices had to be adopted in order to support the spread of the new faith. As Ramadan states:

There is one Islam, and the fundamental principles that define it are those to which all Muslims must adhere.... Western Muslims...have no choice but to go back to the beginning and study their points of reference in order to delineate and distinguish, what in their religion is unchangeable (thabit) from what is subject to change.... (9).

But where are these points of reference? Who can claim to know this truth? Is it the Qu'ran alone? Does this allow for the various practices of Sunnis ${ }^{\text {vi }}$, Shias, and others or just the Salafis? How does it reflect the varying schools of Islamic jurisprudence? Ramadan proposes a way forward that begins "with the message of Islam and its universal principles... to a movement of reform and integration into new environments' (5). Ramadan's position throws up so many questions for those who do not support Salafi interpretations it also leaves no room for diversity of practice or cultural/local context. Moreover, the consequences of this way of thinking cannot be underestimated in a context where Islamists are murdering Muslims who do not submit to their ideology. 
Their hope no doubt is that the world's 1.6 billion Muslims will be under Islamist control. The battle is one of power and for the very soul of Islam.

The insidious imposition of a single Islamic identity has been taking place over many years through the assertion of an 'authentic' Islam. This identity, based on Saudi interpretations of Islam, has taken root and permeates all aspects of Muslim life. Public manifestations of religious piety are evident everywhere due to the pressure on Muslims to be seen to be living the true Islamic life and striving to be better Muslims.

National, ethnic and cultural identities are the casualties in the battle for Islam and Islamic identity. Sufism is the dominant form of Islam among British Muslims of Pakistani origin, which is also the largest Muslim ethnic group in Britain vii. So much of Sufi cultural heritage, practices and traditions are being erased by the Islamists in favour of a more puritanical and orthodox interpretation of Islam. Islamist extremists have attacked and threatened to destroy Sufi shrines in many Muslim majority countries and bombings have taken place at numerous sites resulting in the deaths of hundreds of worshippers to date. Examples of this erasure are given below.

\section{Cloaked and policed by Islamist ideology}

I have witnessed a marked change in the visibility and appearance of Muslim women on the streets and in the media with the imposition of Islamic dress codes for Muslim women. It is almost impossible to see an 
image of a Muslim woman without a hijab in mainstream media which suggests this particular idea of 'Muslimness' is not simply restricted to Muslims but has now found its way into how other British people expect Muslims to be and what makes an authentic Muslim woman. The niqab (full face covering), hijab (headscarf) and abaya (long overgarment) are now the uniform of Muslim women. The implication is that women should be covered lest they tempt men. The dresses worn by South Asian Muslim women for centuries have been replaced by the austere black/blue/brown uniform of the Islamists. The vibrant colours and varying ways of wearing salwar kameez, sarees, and other forms of dress associated with the subcontinent are now less and less visible. The shawls, dupattas and various styles of burqa worn by south Asian women have been replaced by the Arab style hijab/niqab. Streets once filled with Indian/Pakistani boutiques sporting the latest colourful fashions are now filled with abaya shops, hijab stalls and various other forms of religious attire. Perfume has now been replaced by halal, Islamist approved ittar viii free from haram ${ }^{\text {ix }}$ alcohol.

Nadia ${ }^{x}$ told me about her experience:

I wear my hijab because I guess it's what I'm supposed to do - according to my religion. It wouldn't be good if I didn't wear it. I hear what they say about those women who don't. I miss my sarees. The blouses and the embroidery. Even when I go to weddings and wear a saree, it has to be under the abaya. 
It would seem that hijabs are not even removed in all female company. Lubna said:

I don't cover. I choose not to. I was at a funeral and sitting with the women. One of the women started telling me off for not wearing my hijab. She said the angels would hang me by each strand of my hair over the fires of hell for not covering. I was in a room full of women. There were no men.

The imposition of Islamist approved dress codes is now the norm for British Muslims. But it is not limited to adult women. With the proliferation of Muslim faith schools, dress codes for young girls are being cemented. Unlike school uniforms in secular schools which can be removed at the end of the day and at the end of one's school life, the head covering for girls are firmly engraved as acceptable dress for the good Muslim in the future. Tahira said;

My daughter is 5. I didn't want her to go to a Muslim school or to have to wear hijab so young but my husband is worried about what people will think if we don't send her there. He says wearing the hijab now will make it normal so she doesn't have problems in the future.

What began with dress codes has seeped so much further into the daily lives of Muslims. Behaviour is policed in the battle for piety. Saima said;

The maulvi ${ }^{\mathrm{xi}}$ at the madrassa asks the children if I pray at home and if I fast in ramzan ${ }^{x i i}$ I feel like I'm being watched. He told my daughter I would go 
to hell for not wearing hijab and it wasn't good that their father is no longer living with us. What can I do?

Rites of passage have traditionally been framed within religious practices. Prayers and rituals at births, marriages and deaths are all part of our cultural and religious practices. These too have been subject to change over recent years. In my experience, Muslim weddings were colourful funfilled occasions with dancing, music, laughter and men and women in the same space. I fondly remember mehndi ${ }^{\text {xii }}$ parties where women took centre stage and our Punjabi/Muslim/ South Asian identities came together and were celebrated. Some families did hold segregated events but these were very few and far between. Muslim weddings are now austere affairs with mehndi (celebration before the wedding) now deemed irreligious and 'cultural' because of the dancing and singing. Men and women are segregated, music is not allowed. This chimes with Hina's account of her own wedding;

I had dreamt of my wedding day for years. It wasn't what I wanted. Mum and Dad were so worried about what people would say. Men and women were in separate halls. I was sat on stage in the room with the women. Just before my husband came in, there was an announcement made and all the women covered their heads and faces. He came in, a couple of photos were taken and he left. One woman even said 'Why are you taking photos? It's haram'. This isn't what I wanted. 
Parveen told me about comments made by the caterer before her granddaughter's wedding:

When we mentioned there would be a DJ and dancing he kept asking me 'are you sure aunty ji? What will people say? It's not right. We are Muslims?' He even said 'your grand-daughter's in-laws may not be happy with your plans.' I am a Muslim and have been for longer than he has. What is this new Islam? We're Punjabis, we are proud people and know what is wrong and what is right.

One of the most heart wrenching stories I heard was from Guljabeen. She had recently lost her husband after nursing him for many years. A woman in her 70s she was forced by her sons to undertake iddat. ${ }^{\text {iv }}$

My son is very religious. He does not even allow a television or radio in the house. When my husband died, my son spoke to a local alim! about what I had to do. The alim said I must remain in iddat for four months. I am not allowed to answer the phone because I must not speak to a man, answer the door or leave the house for any reason - even to go into the garden. I must stay home and pray. I am an old woman what difference does all this make? Is my loss not enough that I must now endure this prison?

But for Guljabeen, even the prayers that she had to recite were subscribed. I wanted to hold a khatum (prayer gathering) every Thursday for my husband. Just like we used to back home in Pakistan but they tell me 
this is not correct way. No Thursdays, no annual khatum to mark his passing, no giving of clothes to the poor in my husband's name. Why is this wrong now? Are we all Wahabbis?

In addition to dress codes and new ways of marking life events many Muslim women now find themselves subject to an imposition of traditional gender roles with men as guardians and protectors and women as obedient wives and mothers staying within the domestic environment. Nighat is married with three children.

I have a degree from a good university. I want to work but my husband doesn't let me. He keeps telling me that my job is to look after him, the children and the house. Allah says that is my role. He's right it's in my religion. He says our daughter won't go to university as she will be married as soon as we can find a suitable man. This makes me so sad.

I have been researching polygyny amongst British Muslims since 2010. In my research I argue that the emergence of polygyny is connected to the Islamist project. Women in polygynous marriages will only have redress through Sharia courts. Muslim men avoid falling foul of English bigamy laws by only entering into religious marriages. As Rabiya told me:

My parents have been trying to find a husband for me for a few years now. All of the men I have met say that I will not be their only wife. They're so open and tell you upfront. I know it's in our religion and the men tell you this but I don't want this. I'm 25 and my friends say I'll have 
to agree to it or I'll be left on the shelf. I'm getting old and no one will want me.

In recent years I have witnessed the growth of Islamic institutions including Sharia compliant finance institutions, Muslim faith schools in which dress codes and gender roles are reinforced and Sharia courts reinforcing the primacy of faith and an Islamic identity in all aspects of one's life. Pragna Patel (2013) has written about the impact of this on the legal apparatus which involves making state law and policy 'Sharia' compliant and has referred to this as 'shariafication by stealth'. I suggest that the Islamist extremist agenda extends beyond the legal structures and is an extension of the Islamist mission that connects the public and the private spheres and constitutes a re-ordering and reframing of these according to a single, authoritarian version of Islam. These Sharia courts impact disproportionately on women and women's lives as they pronounce on family matters. At a recent meeting held to discuss the Government's planned review of Sharia councils often referred to as Sharia courts, Khola Hassan, an assistant judge at the Islamic Sharia Council stated that $90 \%$ of the users of Sharia courts are women. ${ }^{x v}$ This is not surprising given that only Muslim men have the right to unilaterally bring an end to the marriage whereas a Muslim woman must approach a Sharia Court and terminate the marriage through khul' $\mathrm{a}^{\mathrm{xvi}}$. For women in non registered marriages this may be the only recourse they have to ending an unsatisfactory union. However, Muslim women in registered, recognised 
civil marriages are being advised by religious scholars and some solicitors that they too need a religious divorce which in my view is not the case.

Samreen told me:

I was married to my husband for 10 years. It was terrible. We were divorced in the English courts but then my solicitor who is Muslim too told me I needed an Islamic divorce and he could help me with this. I thought he was right. I went to the court and they kept asking me when we last had sex! What has that got to do with anything? Then they asked my ex to come to the meeting too. I was so frightened. He now knows where I live and keeps saying he'll give a divorce if I give him my son. The judge at the Sharia court said I have to do this. Is this right?

Supporters of Islamic dress codes, institutions and Sharia Courts often argue that they are responding to demand and that women (and men) are exercising their choice and agency. Is this really choice? What are the consequences of rejecting demands to conform to expected norms of behaviour and dress? I know only too well from my work on violence against women and girls over more than three decades the ultimate price paid by many Muslim women for trying to choose their own paths in the context of their own families. The consequences of challenging a global political movement and ultimately what many see as the irrefutable word of God does not bear thinking about. That is not to say that we give up. There are many dissenting voices within Muslim communities and we are 
speaking up and joining with others fighting for freedom, liberty and justice. Silence is not an option.

Yasmin Rehman is a freelance consultant and researcher. She is currently working with Welsh Women's Aid, providing training on equalities, diversity and inclusion for higher education institutions. Yasmin has worked for 30 years predominantly on violence against women, race, faith and gender, and human rights. She co-edited a book, Moving in the Shadows, which examines violence experienced by minority women and girls in the UK. She is working on a second book looking at polygamous marriage and its links to violence and abuse of women and girls. Yasmin is a Board member of EVAW (End Violence Against Women Coalition) and a Trustee of the Centre for Secular Space.

\section{References}

Bacchi, U. 2015. "Libya: Isis wages war on music by burning drums, saxophones and other instruments". International Business Times.

February 19, 2015.

Baily, J. 2001. "The Censorship of Music in Afghanistan". Freemuse.

http://www.rawa.org/music.htm (Accessed June 19, 2016)

Bowen, Innes. 2014. Medina in Birmingham, Najaf in Brent: Inside British Islam $2^{\text {nd }}$ Edition. London. Hurst \& Co.

Denselow, R. 2013. "Mali music ban by Islamists 'crushing culture to impose rule'. The Guardian. Tuesday, 15 January, 2013.

https://www.theguardian.com/music/2013/ian/15/mali-music-banislamists-crushing (Accessed 19 June 2016) 
The Editorial Staff. 2016. "Destruction of Sufi Shrines". The Muslim500.

http://themuslim500.com/2013-2/issues-of-the-day/destruction-of-sufi-

shrines. Accessed 15 June 2016.

Patel, P. 2013. “Multi-Faithism and the Gender Question: Implications of

Government Policy on the Struggle for Equality and Rights for Minority

Women in the UK". In Rehman, Y., Kelly, L., and Siddiqui, H., eds. Moving

in the Shadows: Violence in the Lives of Minority Women and Children.

Farnham. Ashgate Publishing Ltd. 41-58.

Ramadan, T. 2004. Western Muslims and the Future of Islam. New York.

Oxford University Press.

\section{Notes}

'Salafis are fundamentalists who believe in a return to the original ways of Islam. The word 'Salafi' comes from the Arabic phrase, 'as-salaf as-saliheen', which refers to the first three generations of Muslims (starting with the Companions of the Prophet), otherwise known as the Pious Predecessors. ii Wahhabism is a puritanical form of Sunni Islam and is practiced in. Saudi Arabia and Qatar. The word Wahhabi is derived from the name of a Muslim scholar, Muhammad bin Abd al. Wahhab, who lived in the Arabian peninsula during the eighteenth century (1703-1791)

iii. Iconoclasm is literally the destruction of religious icons and other images or monuments for religious or political motives.

${ }^{i v}$ Rev. Dr. Anand Veeraraj was born in India and immigrated with his family to the USA in 1988. He is an ordained minister of the Church of South India and serves as the Pastor of the New Jersey Indian Church and directs the Princeton Forum on Asian Indian Ministries, PC-

USA. http://www.globalringdemo.com/csi/old/print/article/014\%20Anand\%20V eeraraj.pdf

"Jahiliyya refers to the pre-Islamic period, or a time of "ignorance" of monotheism and divine law. In current use, it refers to secular modernity, for example in the work of Abu al-Ala Mawdudi, who viewed modernity as the "new jahiliyyah." Sayyid Qutb interpreted jahiliyyah as the domination of humans over humans, rather than submission of humans to God. The term denotes any government system, ideology, or institution based on values other than those referring to God. To correct this situation, such thinkers propose the 
implementation of Islamic law, values, and principles. Radical groups justify militant actions against secular regimes in terms of jihad against jahiliyyah. vi The followers of Sunni Islam, one of the two major branches of the tradition make up approximately 80 percent of the Muslim population in the world. The Sunni are the majority in most Islamic countries outside of Iran, Iraq, Yemen, and Bahrain. Sunna-translated variously as the "trodden path," "the way," "example," or "habitual practice" - refers to the example or path of the Prophet Muhammad and his followers.

vii Sufism focuses on the spiritual aspects of faith with rituals which include the recitation of prayers, poetry, music, singing and visiting of Sufi shrines which are part of the cultural and religious landscape of the Indian sub-continent.

viii Ittar (Hindi/Urdu) Attar (Arabic) is essential oil derived from botanical sources and is decreed as halal perfume by many Islamic retailers.

ix In Islamic jurisprudence, haram is used to refer to any act that is forbidden by Allah, and is one of five Islamic commandments that define the morality of human action. Acts that are haram are typically prohibited in the religious texts of the Quran and the Sunnah.

${ }^{x}$ The names of interviewees have been changed to protect their identities.

xi Maulvi is an honorific Islamic religious title given to Muslim religious scholars.

xii Urdu/Hindi word for Ramadan, the Muslim month of fasting.

xiii Traditional Pakistani and Hindu or Sikh/Punjabi weddings in India can often be long, ritualistic, and elaborate affairs with many pre-wedding, wedding and post-wedding ceremonies. Different countries and regions of a country celebrate the ceremonies in different ways according to their own marriage customs, rituals, and culture.

${ }^{\text {xiv }}$ A period of seclusion following the death of her husband. Iddat is usually four lunar months and ten days and is to ensure the wife of the deceased man is not pregnant.

xv http://www.islamic-sharia.org/services/

xvi The situation in which the wife initiates divorce proceedings is known as Khul'a. Once the husband agrees to divorce her in exchange for some money or the remission of her dower, the divorce is known as Talaq. It is as valid as the Talaq given by the man of his own initiative. Khul'a depends upon the agreement reached between the two parties. If the husband agrees to give Talaq provided that his wife either abandons her right to the dower (if the dower has not yet been paid) or return back the amount of the dower to the husband (if the dowry has been paid). http://www.islamic-sharia.org/khula/

To cite this article:

Rehman, Y. (2016). Islamisation of the Muslim World. Feminist Dissent, (1), 101-116. Retrieved from:

http://journals.warwick.ac.uk/index.php/feministdissent/article/view/14 